\title{
THE IMPACT OF LOGISTICS PERFORMANCE INDEX UPON GROSS DOMESTIC PRODUCT: MEDIATING ROLES OF FOREIGN DIRECT INVESTMENT AND PATENTS ${ }^{1}$ \\ Umit CELEBI (Orcid Id: /0000-0002-2779-4168) \\ Istanbul Okan University, Turkey
}

\begin{abstract}
Logistics performance plays an important role in economies. This study aimed to determine the impacts of logistics performance index upon gross domestic product through foreign direct investment, patents and global competition index. Data set covered countries accounting for the majority of world gross domestic product. It analyzed the data using structural equation modeling, mediation analyses, simple, multiple regression and sobel test. The result of structural equation modeling showed that logistics performance index has an indirect effect on gross domestic product and this indirect effect takes place through mediating roles of foreign direct investment and patents. Mediation analyses and sobel tests found the following relationships statistically significant: Foreign direct investment fully mediates logistics performance index and gross domestic product. Patents fully mediate logistics performance index and gross domestic product. Patents partially mediate foreign direct investment and gross domestic product. In conclusion, countries that improve their logistics performance index will get higher level of foreign direct investment, patents, global competition index and ultimately gross domestic product.
\end{abstract}

Keywords: LPI, FDI, Patents, GDP, SEM, Mediating Analysis

JEL Codes: C30, F15, F21, O33, O40, R40

\section{INTRODUCTION}

The level of logistics performance is an important determinant on the level of countries' competitiveness and gross domestic product. Markets need timely and efficient flow of goods from one country to another. This requires an high level of logistics performance in the international supply chain. Foreign investors look for favorable logistics environment. Countries consider logistics performance index (LPI) as an important policy tool to attract foreign direct investment (FDI) and new technology. This allows them to reach higher level of national competitiveness and gross domestic product (GDP).

LPI is a relatively new indicator of logistics performance. It shows how countries' logistics performances are fared against each other and with respect to their own past performance. LPI and its relationships with number of limited factors become a subject to some studies. Yet to understand its wider effects and its interplay with variety of many other economic factors further necessitate a continuous research.

The aim of this research is thus to explore the positive impacts of LPI upon GDP through FDI, Patents and Global Competitiveness Index (GCI). The findings would contribute to the literature in two main ways: First, it takes an holistic approach to analyse direct as well as indirect effects. Second, it analyse the indirect effects further to gain insight to mediating roles.

\section{BACKGROUND}

Markets are more and more globally connected due to the tehnological developments and integration. Higher level of integration to the world markets enable production and trade increasingly to take place in global value chains. In these chains, flows of time sensitive intermediary goods are increasing (Baldwin and Gonzalez, 2013; Togan, 2016; Hummels and Schaur, 2013). Increased trade in intermediary goods necessitates multiple border crossings. This elevates the risks of delays and costs. Considering the fact that ten percent increase in transportation costs reduces international trade by twenty percent, the level of impact on the national economies is significant (Limao and Venables, 2001). In order for those delays and costs to be minimised, faster and more efficient quality of inland transport, better border and port transit, and simplified customs processes are cited as important drivers of logistics performance (Kowalski et al., 2015). 
Countries - that are able to reduce those delays and costs - improve their logistics performance index (LPI) and strengthen their positions in the global value chain to attract more FDI, patents reaching higher levels of GCI and GDP (Saslavsky and Sheperd, 2014).

Logistics Management Council defines logistics as part of the supply chain process that plans, conducts and controls the efficient and effective flow and storage of goods, services and information from the production point to the consumption in order to meet customer needs (Long, 2003). Despite logistics was first introduced as a military concept due to its strategic role (Leighton and Coakley, 1995), its crucial role related to business productivity and competitiveness in civilian world also gained high importance (Gereffi and Frederick, 2010). Any improvement in logistics processes add value to the product and services increasing profit margin. Any disruption in these processes reduce competitiveness hence the profit margins (Porter, 1998a). As world production and trade are more and more taking place within global value chains, fast and efficient supply of products and services from one country to another, elevate the importance of performance shown in logistics processes (Memedovic et al., 2008). To improve logistics performance, it is necessary to have measurement criteria and system in place to monitor, control and manage logistics processes (Bowersox, Closs and Cooper, 2002). International LPI is the most comprehensive indicator measuring the performance of logistics processes. It consists of customs, infrastructure, international shipments, timeliness, logistics competences, track and traces sub-indexes. It is published bi-annually by the World Bank since 2007 and its use and importance is increasing (OECD/ITF, 2016). Countries come to recognize logistics performance as an important tool to attract FDI and patents for higher level of GCI and GDP. Among the factors that play a role between LPI and GDP, FDI stands out as an important one.

Liberalization of economies and developments in the field of finance facilitate international capital movements. FDI - being the most persistent and long lasting type of international capital movements - is used to exert business control over foreign operations (World Bank, 2015). While businesses seek growth and expansion by investing in foreign lands, countries aim to attract FDI to accumulate capital and to acquire new technology and knowledge for higher levels of GCI and GDP (Vergil and Karaca, 2010; Balasubramanyam, 2001). FDI's benefits to local economies is strengthened when it brings new technology and knowledge. Thus amongst the factors playing an important role between LPI and GDP, patents is the next one.

The inventions reveal products and processes that did not exist before, continuously improving the technology used and maintaining constant momentum to competitiveness and economic growth (Fagerberg, Mowery and Nelson, 2004). Technology can be measured in number of ways and patents are one of the commonly used indicators of technology published by World Intellectual Property Organization (WIPO). There are some criticisms in the literature with regards to what extent patents are used as a good indicator of technology (Powell and Grodal, 2004; Hall and Harhoff, 2012), but many studies outline patents as an important predictor of the GDP (Griliches,1984; Griliches,1990; Fagerberg and Verspagen, 2002; Smith, 2004). Similar to businesses, nations also compete through their leading industries and technology leaders (Miozzo and Walsh, 2006). Therefore, competitiveness is the third in row explaining the effects of LPI upon GDP.

The World Economic Forum (WEF, 2017) defines competitiveness as a combination of institutions, policies and factors that show the level of efficiency of a country. Adam Smith (1776) as being the founder of modern economics long before laid down the negative effects of monopolization, emphasizing the elimination of barriers to competition and the creation of a more competitive market as one of the key principals of economics. Investment, technology and competition policy, as main drivers of competitiveness, are seen very important in the field of economics (Lall, 2001). GCI is one of the indicators of competitiveness published by WEF annually. Despite its few critics (Lall, 2001), it is a widely used indicator of competitiveness. It comprises more factors and covers more countries than any other similar indices (WEF, 2017).

LPI, FDI, patents and GCI are important indicators for economies. But the analysis of the relationships would be incomplete if GDP is left out. GDP generally refers to the quantitative level in the products and services produced in a country. It is an indicator of nation economic health (World Bank, 2015). GDP is driven more and more by technological progress alongside the traditional factors such as labor and capital (Solow, 1957; Krugman,1994b). 


\section{THE HYPHOTHESES AND THE MODEL}

Hypotheses are developed to reflect dual relationships of the variables in the following way:

\section{LPI and GDP}

There are few studies finding some positive relations especially regarding the drivers of logistics performance on GDP. Countries - that improve their logistics performance by facilitating trade and customs processes - are expected to reach faster GDP (Korinek and Sourdin, 2011; Ferrantino,Tsigas and Geiger, 2015; Hilberry and Zhang, 2015). Sanchez, Tomassian and Perotti (2014) find that the level of economic development goes up as logistics performance increases. Bizoi and Sipos (2014) show that logistics performance is related to higher GDP. Saatçioğlu and Karaca (2011) emphasize the fact that the positive impact of transportation infrastructure on GDP gets particularly higher in developing countries. Hausman, Lee and Subramanian (2013) points to the significant relationship between logistics performance and bilateral trade volume. In the light of the existing literature the following hypothesis is developed:

\section{$\mathrm{H}_{1}$ : LPI has a positive effect on GDP}

\section{LPI and GCI}

Studies show that logistics performance plays an important role on competitiveness. Lower rate of productivity and competitiveness in developing countries is seen to be largely related to the weakness in transport and trade infrastructure (Yeaple and Golub, 2007). One day delay in export process reduces the level of foreign trade by one percent (Djankov, Freund and Pham, 2010). Ten percent delay in transportation reduces import by seven percent (Korinek and Sourdin, 2011). Puertas et. al., (2014) Marti et. al (2014) suggest that logistics performance is much more important in terms of exporting countries than of importing ones. Nunes de Farai and De Souza (2014) suggest that the competitiveness of local businesses can be enhanced by raising the dynamic and competitive in-country logistics performance where bureaucracy acts as a biggest hindrance. Jhawar, Garg and Khera (2014) argue that investing in human capital, improving working and social conditions in logistics processes positively impact logistics performance and increase the competitiveness of businesses benefiting from logistics services. Arvis et al., (2016) argue that increased knowledge and skills in the management of logistics processes play an important role in the competitiveness of countries. According to these observations in the literature, the following hypothesis is reached:

$$
\mathrm{H}_{2} \text { : LPI has a positive effect on GCI }
$$

\section{LPI and FDI}

Enabling international production and trade easier, faster and at a lower cost through higher level of logistics performance is an important factor in attracting FDI into the countries (Balasubramanyam, 2001). This effect seems to be widely supported by a number of studies. In its supporting research, Nunes de Faria and De Souza (2014) found out that logistics performance has a positive effect on FDI. Khadaroo and Seetanah (2010) suggest that transport and logistics infrastructures play a significant influence on attracting FDI. Jacobs and Coolidge (2006) state that governments and poor institutional infrastructures hinder investments. Habib and Zurawicki (2002) show that corruption and bad governance place negative effects on attracting FDI. Ewing-Chow, Junianto and Slade (2014) highlight that the improved legal and institutional infrastructure facilitate trade and FDI helping countries to connect global value and supply chains. Therefore, the following hypothesis is reached in the light of these views:

$\mathrm{H}_{3}$ : LPI has a positive effect on FDI

\section{FDI and Patents}

The effects of FDI on patents is mostly supported in the literature with a few exceptions. Javorcik, Keller and Tybout (2008) found that while FDI adversely affect some local businesses, innovation and productivity are improved due to higher development of competitiveness. Bitzer and Kerekes (2008) argue that the countries that attract FDI gain also technology transfer. Tavares and Young (2005) argue that in order to get higher level of technology absorption and diffusion, the linkages between foreign businesses and local businesses need to be strengthened. Potterie and Lichtenberg (2001) point out that FDI entering knowledge intensive countries generate technology transfer and technical spill over. Technology that was once obtained through import, now is replaced by FDI. Dimelis and Louri (2004) hold that the increased level of competition resulting from FDI induces local firms towards more inventions and patenting activities. Dunning (2008) argues that enterprises increase their investments in foreign countries with the 
aim of accessing knowledge, natural resources, markets and productivity as well as getting an access to information. Petit and Randaccio (1998) suggest that bilateral causality exists between FDI and R\&D, and that FDI positively affects technology diffusion and consumer welfare. Contrary to the above views, technology may not be a natural result of FDI and it may even produce adverse effects. As such, Rodrik (2007) draws attention particularly to the potential negative spillover effects rather than generally expected positive technological diffusion especially when the local absorption capacity of new technology is low. The following hypothesis is reached in the light of all these views:

$\mathrm{H}_{4}$ : FDI has a positive effect on Patents

\section{FDI and GDP}

The literature consists of different views on the impact of FDI on economic growth. Balasubramanyam, Salisu and Sapsford (1996) argue that openness to foreign trade and FDI is positively impacting economic growth more than domestic investment. De Mello (1999) argues that FDI positively impacts economic growth in all countries. This is achieved through higher total factor productivity in developed countries and better capital accumulation in developing ones. Vergil and Karaca (2010) hold that short-term capital flows negatively affect economic growth, whereas FDI and portfolio investments positively affect economic growth. Young and Tavares (2008) underline the importance of FDI on the economic development of developing countries, while drawing attention to the responsibility of foreign enterprises to undertake more of local economic and social duties in the countries. Since FDI come in different forms and purposes, Dunning and Lundan (2008) point to some drawbacks in taking FDI as direct measure and prescription of economic growth and development. Dunning and Narula (2004) suggest that the costs and benefits of FDI may vary according to the extent of technological diffusion, the absorbed capacity of new technologies as well as its nature of being substitutes or complementary to the local sector. Those arguments lead us to the following hypothesis:

\section{$\mathrm{H}_{5}$ : FDI has a positive effect on GDP}

\section{FDI and GCI}

Literature comprises different views and approaches of the impact of FDI on competitiveness. Fu (2012) suggests that FDI triggers technology diffusion. Bitzer and Görg (2009) argues that FDI positively impact competitiveness and productivity due to the liberalization of local markets. In more liberal local markets, better products and services are expected to be exchanged which positively increase knowledge and skill levels of local businesses. Dunning and Lundan (2008) argue that due to the increased level of competition, local resources are re-allocated into more competitive areas. This in turn positively affects economic growth and development. Christiansen and Ogutcu (2003) point to the fact that more efficient and competitive foreign businesses may crowd out local businesses and disturb the competition. In the light of the above observations in the literature, the following hypothesis is developed:

\section{$\mathrm{H}_{6}$ : FDI has a positive effect on GCI}

\section{Patents and GDP}

The literature is almost entirely in consensus on the positive effects of technology on GDP. Schumpeter (1943) underlines the importance of new inventions and innovations as driving forces behind the capitalist engine and economic growth. Fagerberg and Srholec (2005) argue that amongst the determinants openness, financial sophistication, good governance and democracy - that explain economic growth, knowledge is the one which in fact scores the highest. According to Romer $(1986,1990,1989)$ while the physical capital entails decreasing returns, the limitless nature of knowledge enables increasing returns and higher level of efficiency. Freeman and Soete (2004) hold that inventions play a driving role in new investments. Fagerberg and Verspagen (2002) argue that economic growth differentials of countries are increasingly determined by levels of innovation and that patents explain these economic growth differentials better. Glaeser et al. (2004) found that development in human capital positively affects economic growth. Lucas (1988) argues that dissemination of technical knowledge has positive effects on GDP. Fagerberg, Mowery and Verspagen (2009) draw attention to the difficulties in dissemination of information technology effectively due to its rapidly changing nature. According to these theoretical models and studies, the following hypothesis is developed:

\section{$\mathrm{H}_{7}$ : Patents has a positive effect on GDP}




\section{Patents and GCI}

There are variety of opinions in the literature regarding the positive effect of patents on GCI. Burmaoglu (2012) argues that the positive effect of innovation on logistics performance increases the competitive power. Innovation in logistics processes such as containerization increases connectivity to foreign markets, positively impacting competitiveness (Levinson, 2006). Miozzo and Walsh (2006) underline the important impact of innovation on competitiveness. Lall (2001) argues that investment, knowledge and competitiveness play an important role in the economy. Porter (1990) again points to the importance of keeping technological dominance in the country maintaining and enhancing competitiveness. Krugman (1994a) on the other hand, criticizes the relationship, arguing that competitiveness is mainly developed under historical conditions and that adoption of policies to increase it would not be successful if not be a needless attempt. According to these views, the following hypothesis is developed:

\section{$\mathrm{H}_{8}$ : Patents has a positive effect on GCI}

\section{GCI and GDP}

Literature offers different opinions on the positive effect of GCI on GDP. Krugman (1994a) draws attention to the fact that international trade and specialization is developed under historical conditions rather than by economic forces of countries, and that it is not useful if not unnecessary to support strategic industries and trade policies. Equally, it would be very difficult to predict which sector is truly strategic and this may even lead to a hidden way to incentivize the vested interest. Porter $(1998,1990,1996)$ on the other hand supports systematic competitive policies. Because, rather than comparative advantages based on natural resources and market opportunities amongst the countries, creating a business environment based on competitiveness would play even more important role in the economic development. Kogut (1991) points to the importance of domestic markets to understand the level of national competitiveness. According to these arguments in the literature, the following hypothesis is developed:

\section{$\mathrm{H}_{9}$ : GCI has a positive effect on GDP}

According to the hypotheses developed above, the proposed model of the research shown in Figure 1 as below:

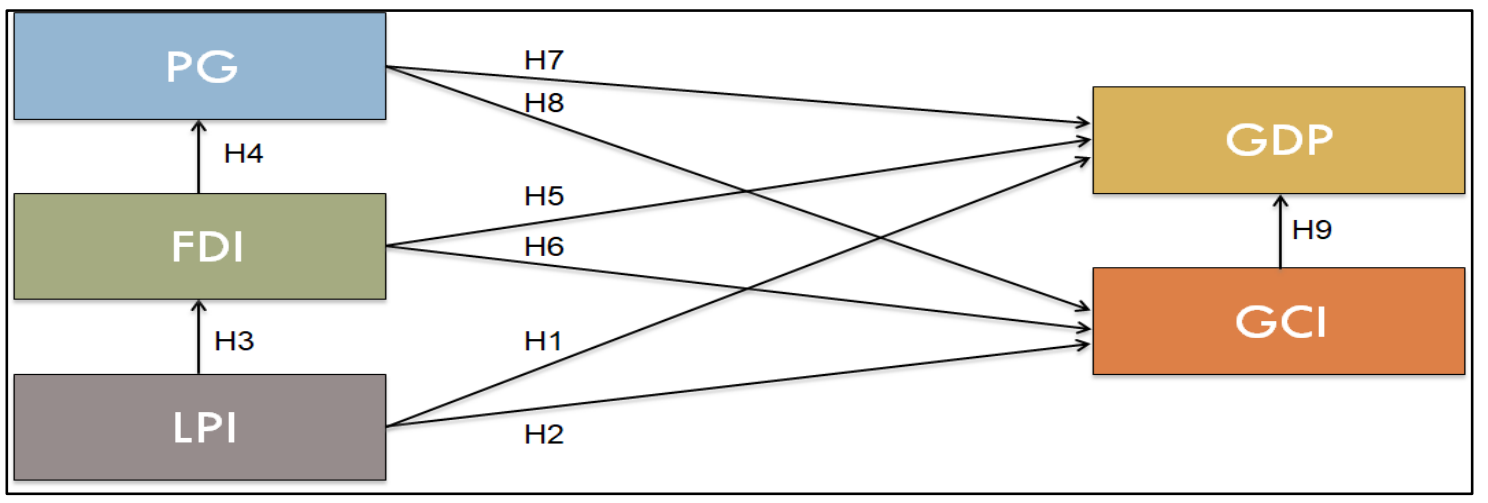

Figure 1 Proposed Model

\section{DATA AND METHODOLOGY}

The study used quantitative secondary data sources. The dataset is based on April 2015 updates covering the years 2007, 2010 and 2012. This study takes 2007 as the first year, because it is the year when LPI was first published by World Bank. After 2007, its publication continued bi-anually in 2010 and 2012. The main motivation behind this study was to explore what one time and linear relationships exist amongst the variables. As its aim was not to analyze what changes have taken place overtime, the period taken was deemed sufficient enough for the purpose and the scope. LPI, FDI and GDP indicators come from World Bank, patents granted (PG) from WIPO and GCI from WEF databases.

LPI is an indicator of logistics performance published World Bank. The data set covers the years 2007, 2010 and 2012. It consists of six components. These are customs, infrastructure, timeliness, international transport, logistics competencies, track and trace. It scales the country's logistics profile from 1 (worst) to 5 (best). 
FDI is an an indicator of longer term foreign capital published by World Bank. The data set covers covers the years 2007, 2010 and 2012. It consists of $10 \%$ or above US dollar long-term capital investment to local businesses, consisting of share capital from the balance of payment accounts, re-investment out of retained earnings, including other long and short term capital excluding divestment.

Patents Granted is an indicator of the technological development published by World Property Rights Organization (WIPO). Data set covers the years 2007, 2010 and 2012.

GCI is an indicator competitiveness published by World Economic Forum (WEF). The data set covers the years 2007, 2010 and 2012 for total of 144 countries ranking them from best to worst on the criteria of economic performance, technological capacity and infrastructures via questionnaires from nearly 5000 administrators from 59 countries that direct businesses and institutions.

GDP is an indicator of national economic output published by World Bank. The data set covers the years 2007, 2010 and 2012. It consists of production level generated within country borders excluding depreciation and incentives, including taxes added to the gross value. This indicator expressed in the local currencies is converted into the official exchange rate of the relevant year and is calculated in US dollars. Since official exchange rates are actually different from the currencies in the market, alternative conversion factors are used for some countries in line with World Bank and OECD National Accounts data files. GDP at purchaser's prices is the sum of gross value added by all resident producers in the economy plus any product taxes and minus any subsidies not included in the value of the products. It is calculated without making deductions for depreciation of fabricated assets or for depletion and degradation of natural resources. Data are in current U.S. dollars. Dollar figures for GDP are converted from domestic currencies using single year official exchange rates. For a few countries where the official exchange rate does not reflect the rate effectively applied to actual foreign exchange transactions, an alternative conversion factor is used.

The data set covers 98 countries and represents $95 \%$ part of the world GDP. It utilized combination of methodologies. Hypotheses were tested first through Structural Equation Modeling (SEM) Path Analysis ${ }^{2}$ to explore direct and indirect relationships. Its visual characteristics helped the researcher to better observe direct and indirect effects. Establishing the mediator roles as a second step, it followed Baron and Kenny methodology, using simple and multiple regression and sobel tests. It utilised SPSS and Amos programs to run the data.

\section{TEST OF HYPOTHESES}

The results of the hypotheses in the research model tested by SEM Path Analysis were assessed according to the following SPSS Amos fit indices: CMIN/DF, CFI, TLI, GFI, RMSA. CMIN is the most basic measure of fit, giving chi-square statistics used as statistical baselines for other goodness of fit indices. It tests the fit of the model.

The CMIN/DF ratio that is below 3 indicates that the model is within acceptable limits (Bayram, 2013:78). Unlike traditional statistical techniques, the researcher hope to reject the zero hypothesis $\left(\mathrm{H}_{0}\right)$ in the SEM. Therefore, the probability (p-value) is expected to be statistically insignificant (Byrne, 2010). Since CMIN (chi-square) value is influenced by the sample size, other fit indices are also necessary. As the sample size increases so as CMIN and p-value, it may mislead the researcher incorrectly concluding that the model does not fit the data (Keith, 2015). Insignificant value of CMIN test signifies the covariance matrix derived from the population is equal to the covariance value derived from the model.

CFI (Comparative Fit Index) taking a value between 0 and 1 indicates the model fit as well. Values greater than 0.95 indicate an acceptable fit, greater than 0.97 indicate a good fit (Schumacker and Lomax, 2010). AGFI (Adjusted goodness of fit index) is calculated by considering the degree of freedom, with values ranging from 0 to 1 . Values greater than 0.9 indicate a good fit (Schumacker and Lomax, 2010).

As sample size increases so as the AGFI values. GFI (Goodness of Fit Index) is related to variance and covariance values as explained by the model (Bayram, 2013). Like AGFI, the GFI value is also sensitive to the sample size. As sample size increases so as the GFI values. GFI also ranges from 0 to 1 . Values above 0.9 indicate a good fit signifying that covariance is calculated between the observed variables (Bayram, 2013). 
RMSEA (The Root Mean Square Error of Approximation) allows calculation of confidence intervals which is sensitive to sample size (Byrne, 2010). Low values are preferred for this indicator.Table 1 shows that the model fit indices of the test carried out are within acceptable values against above criteria.

Table 1 Fit Indices of Proposed Model

\begin{tabular}{ccccc}
\hline CMIN/DF & CFI & AGFI & GFI & RMSEA \\
\hline 1.489 & 0.999 & 0.909 & 0.994 & 0.071 \\
\hline
\end{tabular}

Figure 2 shows the result of the test via SEM path analysis. Some of the hypotheses are not supported in the proposed model:

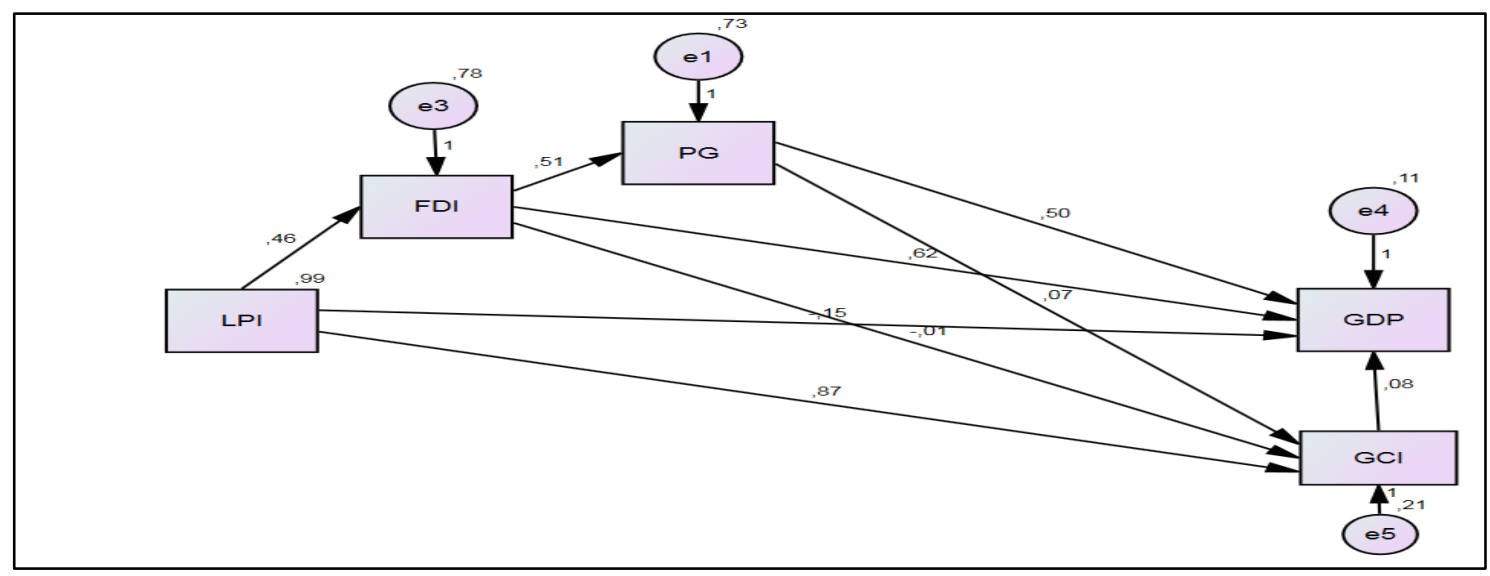

Figure 2 Path Analysis Proposed

Table 2 shows the $\beta$ and $\mathrm{P}$ values for each hypothesis tested. As a result of the test, $\mathrm{H}_{1}, \mathrm{H}_{6}, \mathrm{H}_{8}$ and $\mathrm{H}_{9}$ hypotheses are not supported. Hypotheses that are not supported are removed from the proposed model. Proposed model is revised and the adopted model is reached as Figure 3:

Table 2 Results of Path Analysis

\begin{tabular}{lccl}
\hline Hypotheses & $\boldsymbol{\beta}$ & $\mathbf{P}$ & Supported/Not Supported \\
\hline $\mathrm{H}_{1} \mathrm{LPI} \rightarrow \mathrm{GDP}$ & -0.154 & 0.041 & Not Supported* \\
$\mathrm{H}_{2} \mathrm{LPI} \rightarrow \mathrm{GCI}$ & 0.866 & 0.000 & Supported \\
$\mathrm{H}_{3} \mathrm{LPI} \rightarrow \mathrm{FDI}$ & 0.460 & 0.000 & Supported \\
$\mathrm{H}_{4} \mathrm{FDI} \rightarrow \mathrm{PG}$ & 0.513 & 0.000 & Supported \\
$\mathrm{H}_{5} \mathrm{FDI} \rightarrow \mathrm{GDP}$ & 0,619 & 0.000 & Supported \\
$\mathrm{H}_{6} \mathrm{FDI} \rightarrow \mathrm{GCI}$ & -0.005 & 0.931 & Not Supported** \\
$\mathrm{H}_{7} \mathrm{PG} \rightarrow \mathrm{GDP}$ & 0.496 & 0.000 & Supported \\
$\mathrm{H}_{8} \mathrm{PG} \rightarrow \mathrm{GCI}$ & 0.065 & 0.232 & Not Supported** \\
$\mathrm{H}_{9} \mathrm{GCI} \rightarrow \mathrm{GDP}$ & 0.079 & 0.289 & Not Supported** \\
\hline
\end{tabular}

${ }^{*} \mathrm{H}_{1}$ test result shows a negative sign at $5 \%$ significance level contrary to the expectation. But further mediating analysis showed a positive sign at $\% 1$ significance level in Table 7 . This result confirms the positive effect of LPI on GDP. This effect actually takes place through mediating role of FDI.

${ }^{* *} \mathrm{H}_{6}, \mathrm{H}_{8}$ and $\mathrm{H}_{9}$ test results are contrary to the expectation. This contrast is explained in results of the analyses' section. 


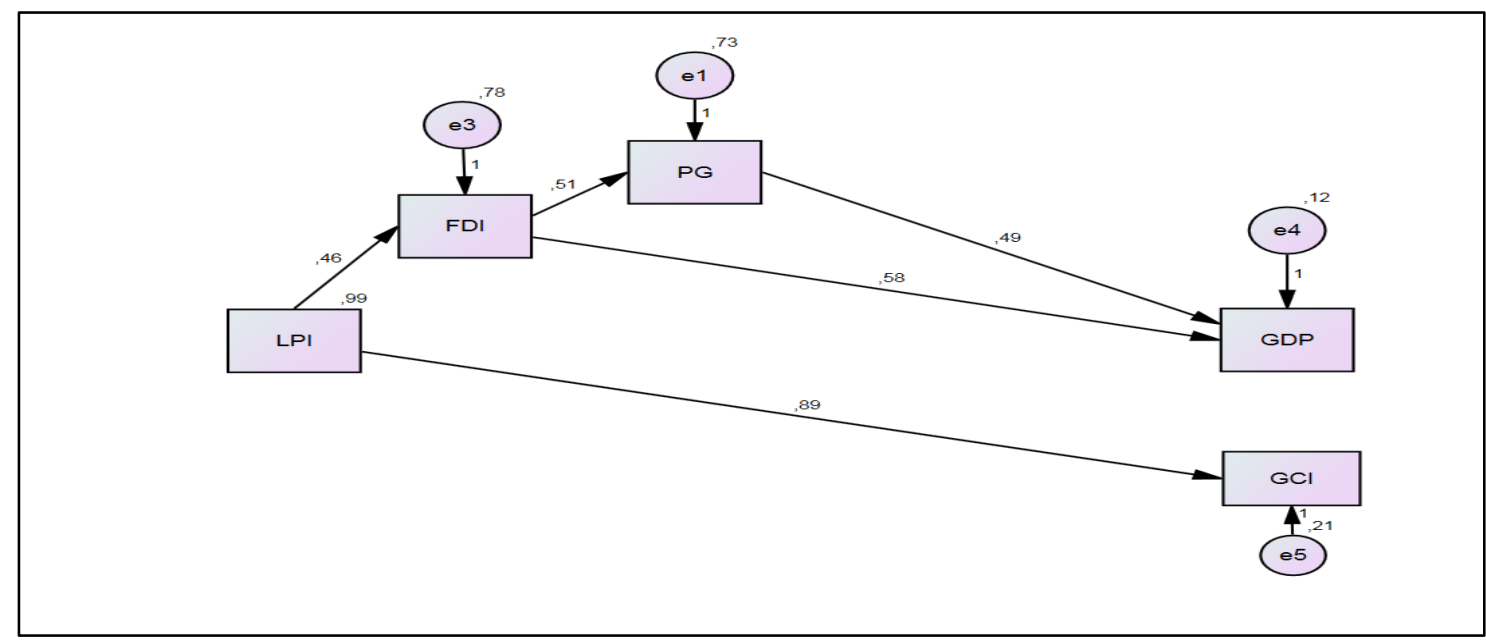

Figure 3 Path Analysis Adopted

Table 3 shows the goodness of fit values of the path analysis adopted:

Table 3 Fit Indices of Adopted Model

\begin{tabular}{ccccc}
\hline CMIN/DF & CFI & AGFI & GFI & RMSEA \\
\hline 1.761 & 0.991 & 0.897 & 0.996 & 0.089
\end{tabular}

In Table 3, adopted model goodness of fit indices contain acceptable values. As a result of the test and analysis carried out by SEM Path Analysis, the final model is shown in Figure 4. Supported and unsupported hypotheses for each path are specified with distinguished lines and arrows.

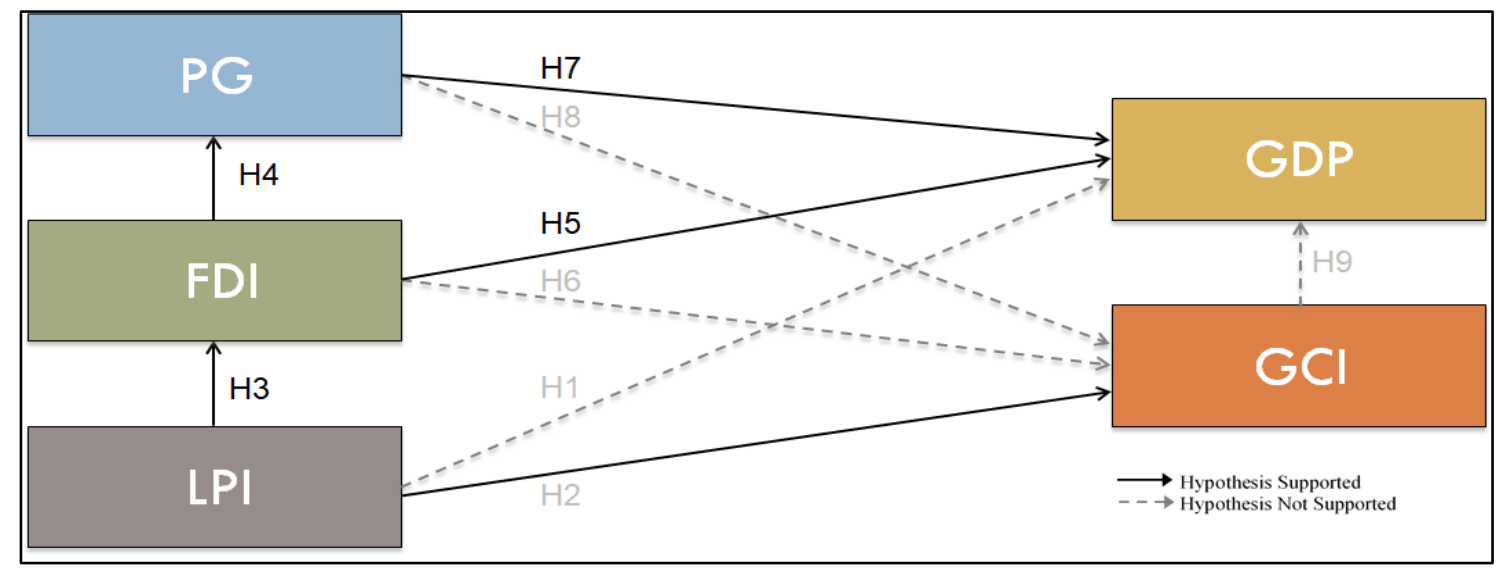

Figure 4 Model

\section{ANALYSES OF MEDIATION}

Out of the Model in Figure 4, hypotheses $\mathrm{H}_{10}, \mathrm{H}_{11}$ and $\mathrm{H}_{12}$ are further developed in anticipation that FDI and PG to be playing mediator variable roles. To test those mediating roles, Baron \& Kenny method, SPSS simple, multiple regression and Sobel test are followed:

\begin{tabular}{|l|l|}
\hline $\mathbf{H}_{\mathbf{1 0}}$ & FDI (MV) is a mediator variable between LPI (IV) and dependent variable GDP (DV) \\
\hline $\mathbf{H}_{\mathbf{1 1}}$ & $\mathrm{PG}(\mathrm{MV})$ is a mediator variable between LPI (IV) and dependent variable GDP (DV) \\
\hline $\mathbf{H}_{\mathbf{1 2}}$ & $\mathrm{PG}(\mathrm{MV})$ is a mediator variable between FDI (IV) and dependent variable GDP (DV) \\
\hline
\end{tabular}

IV: Independent Variable; DV: Dependent Variable; MV: Mediator Variable 
In order to test a mediating relation, there needs to be a significant correlation between variables as a first step. In the second step, the Baron and Kenny analysis method should be followed. According to Baron and Kenny (1986) mediating effects arise when the following conditions are met:

i) A change in the independent variable leads to a change in the mediator variable,

ii) A change in the mediator variable leads to a change in dependent variable,

iii) When the mediator and independent variables are both included in the analysis together, the previously meaningful effect of the independent variable on the dependent variable falls or become meaningless.

Table 4 Model Correlation

\begin{tabular}{lcccc}
\hline & LPI & FDI & PG & GDP \\
\hline LPI & - & $0,460 * * *$ & $0,360 * * *$ & $0,364 * * *$ \\
FDI & $0,460 * * *$ & - & $0,513 * * *$ & $0,837 * * *$ \\
PG & $0,330 * * *$ & $0,513 * * *$ & - & $0,791 * * *$ \\
GDP & $0,364 * * *$ & $0,837 * * *$ & $0,791 * * *$ & - \\
\hline \multicolumn{2}{c}{$* * \mathrm{P}<0.01$} & & &
\end{tabular}

Since the Pearson correlation coefficients in Table 4 show strong and significant correlation between the variables, in the second step sub-hypotheses and regression equations are established according to Baron and Kenny analysis method:

\section{- FDI mediator variable (between LPI and GDP)}

$\mathrm{H}_{10}$ : Mediator variable role of FDI between LPI and GDP is tested with the following sub-hypotheses and regression equations:

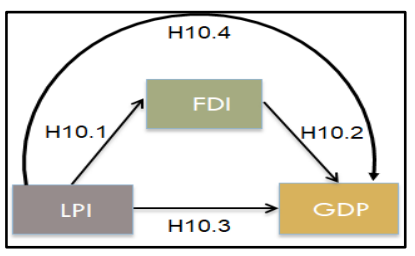

\begin{tabular}{|l|l|}
\hline $\mathbf{H}_{\mathbf{1 0 . 1}}$ & FDI is positively affected by LPI \\
\hline $\mathbf{H}_{\mathbf{1 0 . 2}}$ & GDP is positively affected by FDI \\
\hline $\mathbf{H}_{\mathbf{1 0 . 3}}$ & GDP is positively affected by LPI \\
\hline $\mathbf{H}_{\mathbf{1 0 . 4}}$ & FDI is a mediator variable between LPI (IV) and GDP (DV) \\
\hline
\end{tabular}

Figure 5 FDI mediator variable

The following regression equations are tested by the simple, multiple regression and the Sobel test:

$$
\begin{aligned}
& \text { Model 1: } \mathrm{FDI}=\beta 0+\beta 1 \mathrm{LPI}+\varepsilon \\
& \text { Model 2: } \mathrm{GDP}=\beta 0+\beta 1 \mathrm{LPI}+\varepsilon \\
& \text { Model 3: } \mathrm{GDP}=\beta 0+\beta 1 \mathrm{LPI}+\beta 2 \mathrm{FDI}+\varepsilon
\end{aligned}
$$

Regression analysis and Sobel test results are presented in Table 5:

Table 5 Hypotheses Results

\begin{tabular}{lccc}
\hline & Model 1 & Model 2 & Model 3 \\
\hline LPI $\rightarrow$ FDI & $0,460^{* * *}$ & - & - \\
$\mathrm{LPI} \rightarrow$ GDP & - & $0,364^{* * *}$ & $-0,026$ \\
$\mathrm{FDI} \rightarrow$ GDP & - & - & $0,848^{* * *}$ \\
$\mathrm{R}^{2}$ & 0,211 & 0,133 & 0,700 \\
Adjusted $\mathrm{R}^{2}$ & 0,203 & 0,124 & 0,694 \\
$\mathrm{~F}$ & $25,721^{* * *}$ & $14,691^{* * *}$ & $111,010^{* * *}$ \\
\hline & Sobel Test Statistics & $\mathbf{P}$ & \\
$\mathrm{LPI} \rightarrow$ FDI $\rightarrow$ GDP & 4,73224523 & 0,00 & \\
\hline$* * * \mathrm{P}<0.01$ & & &
\end{tabular}

Table 5 gives the test results of hypotheses and regression equations. Accordingly, the change in LPI (IV) causes the change in the FDI (MV) (Model 1). In the same way, change in LPI (IV) causes change in GDP (DV) (Model 2). When the mediator variable and the independent variable (FDI and LPI respectively) are both included in the same model together, the effect of LPI (IV) on GDP (DV) falls and becomes 
meaningless (Model 3). In Table 5, Sobel test gives also a significant p-value. For this reason, all sub hypotheses are accepted and the full-mediator variable role of FDI between LPI (IV) and GDP (DV) is found statistically significant.

\section{- PG mediator variable I (between LPI and GDP)}

$\mathrm{H}_{11}$ : Mediator variable role of PG between LPI and GDP is tested with the following sub-hypotheses and regression equations:

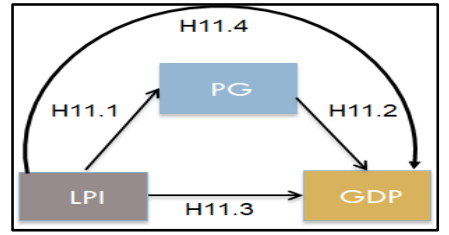

\begin{tabular}{|l|l|}
\hline $\mathbf{H}_{11.1}$ & PG is positively affected by LPI \\
\hline $\mathbf{H}_{11.2}$ & GDP is positively affected by PG \\
\hline $\mathbf{H}_{11.3}$ & GDP is positively affected by LPI \\
\hline $\mathbf{H}_{11.4}$ & PG is a mediator variable between LPI (IV) and GDP (DV) \\
\hline
\end{tabular}

Figure 6 PG mediator variable - I

The following regression equations are tested by the simple, multiple regression and the Sobel test:

$$
\begin{aligned}
& \text { Model 1: } \mathrm{PG}=\beta 0+\beta 1 \mathrm{LPI}+\varepsilon \\
& \text { Model 2: GDP }=\beta 0+\beta 1 \mathrm{LPI}+\varepsilon \\
& \text { Model 3: GDP }=\beta 0+\beta 1 \mathrm{LPI}+\beta 2 \mathrm{PG}+\varepsilon
\end{aligned}
$$

Regression analysis and Sobel test results are presented in Table 6:

Table 6 Hypotheses Results

\begin{tabular}{lccc}
\hline & Model 1 & Model 2 & Model 3 \\
\hline $\mathrm{LPI} \rightarrow$ PG & $0,330^{* * *}$ & - & - \\
$\mathrm{LPI} \rightarrow$ GDP & - & $0,364^{* * *}$ & 0,116 \\
$\mathrm{PG} \rightarrow$ GDP & - & - & $0,752^{* * *}$ \\
$\mathrm{R}^{2}$ & 0,109 & 0,133 & 0,637 \\
Adjusted $\mathrm{R}^{2}$ & 0,100 & 0,124 & 0,629 \\
$\mathrm{~F}$ & $11,725^{* * *}$ & $14,691^{* * *}$ & $83,380^{* * *}$ \\
\hline & Sobel Test Statistics & $\mathbf{P}$ & \\
$\mathrm{LPI} \rightarrow \mathrm{PG} \rightarrow$ GDP & 3,29512436 & 0,00 & \\
\hline$* * * \mathrm{P}<0.01$ & & &
\end{tabular}

Table 6 gives the test results of hypotheses and regression equations. Accordingly, the change in LPI (IV) causes the change in the PG (MV) (Model 1). In the same way, change in LPI (IV) causes change in GDP (DV) (Model 2). When the mediator variable and the independent variable (PG and LPI respectively) are both included in the same model together, the effect of LPI (IV), on GDP (DV) falls and becomes meaningless (Model 3). In Table 6, Sobel test gives also a significant p-value. For this reason, all sub hypotheses are accepted and the full-mediator variable role of PG between LPI and GDP is found statistically significant.

\section{- PG mediator variable II (between FDI and GDP)}

$\mathrm{H}_{12}$ : Mediator variable role of PG between FDI and GDP is tested with the following sub-hypotheses and regression equations:

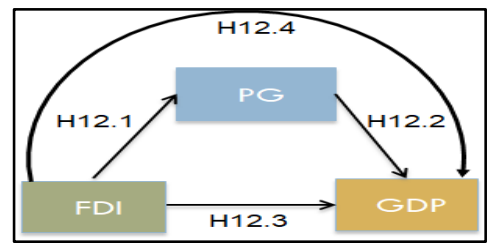

\begin{tabular}{|l|l|}
\hline $\mathbf{H}_{12.1}$ & PG is positively affected by FDI \\
\hline $\mathbf{H}_{12.2}$ & GDP is positively affected by PG \\
\hline $\mathbf{H}_{12.3}$ & GDP is positively affected by FDI \\
\hline $\mathbf{H}_{12.4}$ & PG is a mediator variable between FDI (IV) and GDP (DV) \\
\hline
\end{tabular}

Figure 7 PG mediator variable - II 
The following regression equations are tested by the simple, multiple regression and the Sobel test:

$$
\begin{aligned}
& \text { Model 1: } \mathrm{PG}=\beta 0+\beta 1 \mathrm{FDI}+\varepsilon \\
& \text { Model 2: } \mathrm{GDP}=\beta 0+\beta 1 \mathrm{FDI}+\varepsilon \\
& \text { Model 3: } \mathrm{GDP}=\beta 0+\beta 1 \mathrm{FDI}+\beta 2 \mathrm{PG}+\varepsilon
\end{aligned}
$$

Regression analysis and Sobel test results are presented in Table 7:

Table 7 Hypotheses Results

\begin{tabular}{lccc}
\hline & Model 1 & Model 2 & Model 3 \\
\hline FDI $\rightarrow$ PG & $0,513^{* * *}$ & - & - \\
$\mathrm{FDI} \rightarrow$ GDP & - & $0,837^{* * *}$ & $0,585^{* * *}$ \\
$\mathrm{PG} \rightarrow$ GDP & - & - & $0,491^{* * *}$ \\
$\mathrm{R}^{2}$ & 0.263 & 0.700 & 0.877 \\
$\mathrm{Adjusted} \mathrm{R}^{2}$ & 0.256 & 0.697 & 0.875 \\
$\mathrm{~F}$ & $34,297^{* * *}$ & $223,803^{* * *}$ & $338,986^{* * *}$ \\
\hline & Sobel Test Statistics & $\mathbf{P}$ & \\
$\mathrm{FDI} \rightarrow \mathrm{PG} \rightarrow$ GDP & 5.21690211 & 0.00 & \\
$\quad * * * \mathrm{P}<0.01$ & & &
\end{tabular}

Table 7 gives the test results of hypotheses and regression equations. Accordingly, the change in FDI (IV) causes the change in the PG (MV) (Model 1). In the same way, change in FDI (IV) causes change in GDP (DV) (Model 2). When the mediator variable and the independent variable (PG and FDI respectively) are both included in the same model together, the effect of FDI (IV) on GDP (DV) falls yet continue to be meaningful (Model 3). In Table 7, Sobel test gives also a significant p-value. For this reason, all sub hypotheses are accepted and the partial-mediator variable role of PG between FDI and GDP is found to be statistically significant.

\section{RESULTS OF THE ANALYSES}

The first hypothesis - testing the direct positive effect of logistics performance upon economic growth - has not been supported. Some empirical studies have shown that LPI is closely related to GDP (Bizoi and Sipos, 2014, Nune de Faria and Silvestre de Souza, 2014, Sanchez et al., 2014). The model of this research finds that the effect of LPI upon GDP is realized indirectly via mediating roles of FDI and Patents.

The second hypothesis - testing the direct positive impact of LPI on GCI has been supported. The third hypothesis - testing direct positive impact of logistics performance on FDI - has been supported. The fourth hypothesis - testing direct positive impact of FDI on Patents - has been supported. The fifth hypothesis testing direct positive impact of FDI on GDP has been supported and this research finds that FDI's effect on GDP is direct as well as indirect through Patents.

The sixth hypothesis - testing the direct positive impact of FDI on the level of GCI - has not been supported. Although few researches in the literature consist of views supporting the relation (Bitzer and Görg 2009; Dunning and Lundan, 2008), few others in contrast argue that competitiveness is based mainly on the logistics performance in the supply chain (Levinson, 2006) and local characteristics of the countries (Porter, 1998b).

The seventh hypothesis for the direct positive effect of Patents on GDP has been supported in line with literature.

The eigth hypothesis regarding the direct positive effect of Patents on the level of GCI has not been supported. The result of the test is not compatible with the literature (Best, 2001). One of the reasons for this incompatibility would be to do with the nature of some aspects of the GCI used as an indicator of competitiveness which attracts some criticism in the literature (Lall, 2001).

The ninth hypothesis - testing direct positive impact of the level of GCI on GDP - has not been supported. This relationship is partially in line with the views in the literature. Some studies show that openness to trade - being a condition of global competitiveness - does not affect GDP (Fagerberg and Srholec, 2005).

The tenth hypothesis for the mediator role of FDI between LPI and GDP has been supported. This role is found to be full. In the literature, there are findings of the indirect effects of FDI on GDP. But indirect effects of LPI on GDP through the mediator role of FDI is not observed. 
The eleventh hypothesis for the mediator role of Patents between LPI and GDP has been supported. This role is found to be full. There are number of studies finding a significant relationship between LPI and national innovation systems (Burmaoğlu, 2012) as well as effect of technological development on GDP. But indirect effect of LPI on GDP through mediator role of Patents is not observed.

The twelfth hypothesis testing for the mediator role of Patents between FDI and GDP has been supported. In this study, this role is found to be partial.

\section{CONCLUSION}

This paper investigated the impact of LPI upon GDP through FDI, Patents and GCI. It found direct as well as indirect effects. Its main findings are as follows: First, LPI affects GDP through the mediating roles of FDI and Patents. Second, FDI affects GDP directly as well as indirectly and this indirect effect takes place through mediating role of Patents. Third, LPI affects GCI directly. Fourth, Patents affect GDP directly.

The results would contribute to the literature in two main ways: First, it offers an holistic model to analyze the complex relationships. Second, it finds both direct and indirect effects. Analysing the indirect effects further, it finds that indirect effects of LPI upon GDP actually takes place through mediating roles of FDI and Patents.

The results suggest following policy implications: LPI is an important determinant to reach higher level of FDI, Patents, GCI and GDP. To reach higher level of LPI in turn necessitates development of its drivers concurrently. These - besides the improvement of trade and transport physical infrastructure - include development of logistics quality, competence, facilitatation of customs and trade for timely and efficient flow of goods cross border.

This research was limited to explore one time linear relationships amongst the variables. Subsequent research taking into account of the time dimension and of non-linear relationships may contribute to the field further. 


\section{REFERENCES}

Arvis, J-F., Saslavsky D., Ojala L., Shepherd B., Busch C., Raj A., Naula T. (2016). Connecting to Compete 2016, Trade Logistics in the Global Economy, LPI and Its Indicators, Washington, World Bank.

Bayram, Nuran. (2013).Yapısal Eşitlik Modellemesine Giriş Amos Uygulamaları. 2.bs., Bursa, Ezgi Yayınevi.

Balasubramanyam, V.N. (2001). FDI in Developing Countries: Determinants and Impact, OECD Global Forum on International Investment.

Balasubramanyam, V.N, Salisu, M, Sapsford D. (1996). FDI and Growth in EP and IS countries, Economic Journal, 106(434), pp. 92-105, https://doi.org/10.2307/2234933

Baldwin, R. E., Lopez Gonzales J. (2013). Supply Chain Trade: A Portrait of Global Patterns And Several Testable Hypotheses, Cambridge, National Bureau of Economic Research Working Paper, No. 18957.

Best, Michael. H. (2001). The new Competitive Advantage: The renewal of American Industry. Oxford, Oxford University Press.

Bitzer, J., Görg, H. (2009). FDI, Competition and Industry Performance, Oxford, The World Economy, Blackwell Publishing, pp.221-233, https://doi.org/10.1111/j.1467-9701.2008.01152.x

Bitzer, J., Kerekes, M. (2008). Does FDI transfer technology across borders?, Economic Letters, 100, pp. 355-358, https://doi.org/10.1016/j.econlet.2008.02.029

Bizoi, A. C., Sipos, C. (2014). Logistics Performance and Economic Development - A comparison within the European Union, Paper presented at International Conference on Applied Business and Economics 2014 (ICABE 14).

Bowersox, Donald J., Closs David J., Cooper Bixby M. (2002). Supply Chain Lojistics Management, New York, McGraw-Hill.

Byrne, Barbara M. (2010). SEM with AMOS, Basic Concepts, Applications, and Programming, 2. ed., New York, Multivariate Application Series, Routledge Taylor \& Francis Group.

Burmaoğlu, S. (2012). Ulusal İnovasyon Göstergeleri ile Ulusal Lojistik Performansı Arasındaki İlişki: AB Ülkeleri Üzerine Bir Araştırma, Ege Akademik Bakış, 12(2), pp.193-208, https://doi.org/ 10.21121/eab.2012219534

Çelebi, Ümit (2018). Lojistiğin Ekonomideki Rolü, İstanbul, 1.ed., Ati Yayınları.

Çelebi, Ümit (2018). The Impacts of Logistics Performance upon Economic Growth: A Proposal of Conceptual Model From The Perspective of EU-Turkey Customs Union Dynamic Effects, Istanbul University Institute of Social Sciences.

Christiansen, H., Öğütçü, M. (2003). FDI for development: maximising benefits, minimising costs, OECD Global Forum on International Investment.

De Mello, L.R. (1999). FDI-Led Growth: evidence from time series and panel data, Oxford Economic Papers, 51(1), pp.133-151, https://doi.org/10.1093/oep/51.1.133

Dimelis, S., Louri, H. (2004). FDI and Technology Spillovers: Which Firms Really Benefit?, Review of World Economics, 140(2), 230-253, https://doi.org/ 10.1007/BF02663647

Djankov, S., Freund C., Pham C. (2010). Trading on Time, Review of Economics and Statistics, 92(1), pp.166-173, https://doi.org/10.1162/rest.2009.11498

Dunning, J. H. (2008). Institutional Reform, FDI and the Locational Competitiveness of European Transition Economies, FDI, Location and Competitiveness Progress in International Business Research, Oxford, Elsevier Ltd, Ed. John H. Dunning, Philippe Gugler, UK, 2, pp.175-201.

Dunning, John H., Narula Rajneesh (2004). Multinationals and Industrial Competitiveness, UK, Edward Elgar Publishers.

Dunning, John H., Lundan, Sarianna M. (2008). Multinational Enterprises and the Global Economy, 2. ed, Cheltenham, Edward Elgar Publishing. 
Ewing-Chow, M., Losari J., Slade, M. V. (2014). The facilitation of trade by the rule of law: the cases of Singapore and ASEAN, Connecting to global markets, Geneva, WTO Publications, chapter 9, pp.129-146.

Fagerberg, J., Verspagen, B. (2002). Technology-gaps, innovation diffusion and transformation: an evolutionary interpretation, Research Policy, 31, pp.1291-1304.

Fagerberg, Jan, David Mowery C., Bart Verspagen (2009). Innovation, Path Dependency and Policy, The Norwegian Case, Oxford University Press.

Fagerberg, Jan, David Mowery C., Richard Nelson R. (2004). Innovation a guide to the literature, Ed. Jan Fagerberg, David Mowery C., Richard Nelson R., Oxford Handbook of Innovation, Oxford, Oxford University Press, pp.1-26.

Fagerberg, J., Srholec, M. (2005). Catching Up: What are the Critical Factors for Success? UNIDO World Industrial Development Report, pp.1-88.

Ferrantino, M., Tsigas, M., Geiger, T. (2015). Enabling Trade: Catalysing Trade Facilitation Agreement Implementation in Brazil, World Economic Forum, Geneva, pp.1-27.

Freeman, Chris, Luc Soete (2004). Yenilik İktisadı, 4.bs., Çev. Ergun Türkcan, Ankara, Tübitak Yayınları.

$\mathrm{Fu}, \mathrm{X}$. (2012). FDI and Managerial Knowledge Spillovers through the Diffusion of Management Practices, Oxford, Journal of Management Studies, pp.1-30, https://doi.org/10.1111/j.1467-6486.2011.01036.x

Gereffi, G., Stacey, F. (2010). The Global Apparel Value Chain Trade and the Crisis, Challenges and Opportunities for Developing Countries, The World Bank, Policy Research Working Paper, No. 5281.

Glaeser, E. L., La Porta R., Lopez-de-Silanes F., Shleifer A. (2004). Do Institutions cause growth?, Journal of Economic Growth, 9, 271-303, https://doi.org/10.3386/w10568

Habib, M., Zurawicki L. (2002). Corruption and FDI, Journal of International Business Studies, 33(2), pp.291-307.

Hausman, W. H., Lee, H. L., Subramanian, U. (2013). The impact of Logistics Performance on Trade, Production and Operations Management, 22(2), 236-252, https://doi.org/10.1111/j.19375956.2011.01312.x

Hilberry, R. H., Zhang, X. (2015). Policy and Performance in Customs, Evaluating the Trade Facilitation Agreement, World Bank Group Policy Research Working Paper, No. 7211.

Hummels, D. L., Schaur, G. (2013). Time as a Trade Barrier, American Economic Review, 103(7), Issue 7, pp.2935-2959, https://doi.org/10.1257/aer.103.7.2935

Jacobs, S., Coolidge, J. (2006). Reduce Administrative Barriers to Investment Lessons Learned, FIAS, International Finance Corporation and World Bank, Occasional Paper, No. 17.

Javorcik, B., Keller, W., Tybout, J. (2008). Openness and Industrial Response a Wal-Mart World: A case study of Mexican soaps, Detergents, and Surfactant Producers, The World Economy, Blackwell Publishing Ltd, pp.1558-1580, https://doi.org/10.1111/j.1467-9701.2008.01142.x

Jhawar, A., Garg S. K., Shikha K. N. (2014). Analysis of skilled work force effect on the logistics performance index - case study from India, Springer Logistics Research, 7(117), pp.1-10, https://doi.org/10.1007/s12159-014-0117-9

Keith, Timothy Z. (2015). Multiple Regression and Beyond, An Introduction to Multiple Regression and SEM, 2. ed., New York, Routledge.

Khadaroo, A., Seetanah, J. J. (2010). Transport Infrastructure and Foreign Direct Invesment, Journal of International Development, 22, pp.103-123, https://doi.org/10.1002/jid.1506

Kogut, B. (1991). Country Capabilities and The Permeability of Borders, Strategic Management Journal, 12(12), pp.33-47, https://doi.org/10.1002/smj.4250120905

Korinek, J., Patricia S. (2011). To What Extent Are High-Quality Logistics Services Trade Facilitating?, OECD Trade Policy Papers, No. 108. 
Kowalski, P., Gonzales, J. L., Ragoussis A., Ugarte, C. (2015). Participation of Developing Countries in Global Value Chains: Implications for Trade and Trade-Related Policies, OECD Trade Policy Papers, No. 179, http://dx.doi.org/10.1787/5js331fw0xxn-en

Krugman, Paul. R. (1994a). The Age of Diminished Expectations, London, MIT Press.

Krugman, Paul. R (1994b). The Myth of Asia's Miracle, Foreign Affairs, 73(6), pp.62-78, http://doi.org/10.2307/20046929

Lall, S. (2001). Competitiveness Indices and Developing Countries: An Economic Evaluation of the Global Competitiveness Report, World Development, 29(9), pp.1501-1525, http://doi.org/10.1016/S0305750X(01)00051-1

Lei, P-W., Wu, Q. (2007). Introduction to SEM: Issues and Practical Considerations, Educational Measurement Issues and Practice, 26(3), pp.33-43, http://doi.org/10.1111/j.1745-3992.2007.00099.X

Leighton, Richard M., Coakley, Robert W. (1995). Global Lojistics and Strategy 1940-1943, Washington, Center of Military History, United States Army.

Levinson, Marc (2006). The Box, How the Shipping Container Made the World Smaller and the World Economy Bigger, Princeton New Jersey, Princeton University Press.

Limao, N., Venables, A. J. (2001). Infrastructure, Geographical Disadvantage, Transport Costs, and Trade, The World Economic Review, 15(3), pp.451-479.

Long, Douglas (2003). International Logistics Global Supply Chain Management, Massachusetts, Kluwer Academic Publishers.

Lucas, R.E. (1988), On the mechanics of economic development, Journal of Monetary Economics, 22, pp.342, https://doi.org/10.1016/0304-3932(88)90168-7

Puertas, R., Marti, L., Garcia, L. (2014). Logistics Performance and export competitiveness: European experience, Empirica, 41, pp.467-480.

Marti, L., Puertas, R., Garcia, L. (2014). The importance of Logistics Performance Index in international trade, Applied Economics, 2014, 46(24), pp.2982-2992, https://doi.org/10.1080/00036846.2014.916394

Memedovic, O., Ojala, L., Rodrigue, J. P., Naula, T. (2008). Fuelling the global value chains:what role for logistics capabilities?, Int. J. Technological Learning, Innovation and Development, 1(3), pp.353-374, https://doi.org/10.1504/IJTLID.2008.019978

Miozzo, Marcela, Walsh, Vivien (2006). International Competitiveness and Technological Change, Oxford, Oxford University Press.

Nunes de Faria, R., Caio, S de S., Vieira, J. G. V. (2014). Evaluation of Logistics Performance Indexes of Brazil in the international trade, Ram Rev Adm Mackenzie,16(1), pp.213-235, http://dx.doi.org/10.1590/1678-69712015/administracao.v16n1p213-235

OECD/ITF (2016). Logistics Development Strategies and Performance Measurement, Paris, International Transport Forum, Roundtable Report, No. 158.

Petit, M. L., Randaccio F. S. (1998). Endogenous R\&D and FDI in international oligopolies, International Journal of Industrial Organization, Elsevier, 18, pp.339-367, http://dx.doi.org/10.1016/S01677187(98)00028-9

Porter, M. E. (1990). The Competitive Advantage of Nations, Harvard Business Review, 90(2), pp.73-93.

Porter, M. E. (1996). What Is Strategy?, Harvard Business Review 74, no. 6(November-December), pp.6178.

Porter, Michael E. (1998a). Competitive Advantage Creating and Sustaining Superior Performance, New York, The Free Press.

Porter, M. E. (1998b). Clusters and the New Economics of Competition, Harvard Business Review, pp.7790. 
Potterie, B. P. P., Lichtenberg, F. (2001). Does FDI Transfer Technology Across Borders?, Review of Economics and Statistics, 83(3), pp.490-497, https://doi.org/10.1162/00346530152480135

Rodrik, Dani (2007). One Economics Many Recipes, Globalization, Institutions, And Economic Growth, New Jersey, Princeton University Press.

Romer, P. M. (1986). Increasing returns and long run growth, Journal of Political Economy, 94, pp.10021037, https://doi.org/10.1086/261420

Romer, P. M. (1989). Human Capital and Growth, National Bureau of Economic Research, Working Paper, No. 3173.

Romer, Paul M. (1990). Endogenous Technological Change, Journal of Political Economy, 98(5), pp.71102, https://doi.org/10.3386/w3210

Saatçioğlu, C. (2005). Ulusal Yenilik Sistemi Çerçevesinde Uygulanan Bilim ve Teknoloji Politikaları: İsrail, AB ve Türkiye Örneği, Sosyal Bilimler Dergisi, 1, pp.179-198.

Saatçioğlu, C., Karaca, O. (2011). Ulaştırma Altyapısı-Ekonomik Büyüme İlişkisi: Panel Veri Analizi, Cag University Journal of Social Sciences, 8(2), pp.179-198.

Sanchez, R. J., Cipoletta T. G., Perrotti, D. E (2014). Economic Development and Logistics Performance, Revista de Economia Mundial, 38, pp.27-48.

Saslavsky, D., Shepherd, B. (2014). Facilitating International Production Networks: The Role of Trade Logistics, Journal of International Trade and Economic Development, 23(7), pp.979-999, https://doi.org/10.1080/09638199.2013.811534

Schwab, K. (2016). The Fourth Industrial Revolution, Geneva, WEF.

Schumacker, R. E., Lomax, R. G. (2010). A Beginner's Guide to SEM, 3.ed., New York, Routledge.

Schumpeter, Joseph A. (1943). Capitalism, Socialism \& Democracy, London, Routledge Publishers.

Smith, Adam (1776). An Inquiry into the Nature and Causes of the Wealth of Nations, Chicago, Ed. Edwin Cannan, Chicago Press.

Sobel, M. E. (1982). Confidence Intervals for Indirect Effects in Structural Equation Models, Sociological Methodology, 13, pp.290-312, http://dx.doi.org/10.2307/270723

Solow, R. (1956). A contribution to the theory of Economic Growth, Quarterly Journal of Economics, 70(1), pp.65-94, https://doi.org/10.2307/1884513

Solow, R. (1957). Technical Change and the Aggregate Production Function, Review of Economics and Statistics, 39(3), pp.312-320, https://doi.org/10.2307/1926047

Togan, Subidey (2016). The Liberalization of Transportation Services in the EU and Turkey, Oxford, Oxford Publishing, https://doi.org/10.1093/acprof:oso/9780198753407.001.0001

Vergil, H., Karaca, C. (2010). Gelişmekte Olan Ülkelere Yönelik Uluslararası Sermaye Hareketlerinin Ekonomik Büyüme Üzerindeki Etkisi: Panel Veri Analizi, Ege Akademik Bakış, 10(4), pp.1207-1216.

Vernon, R. (1966). International Investment and international trade in the product life cycle, Qurterly Journal of Economics, 80, pp.190-207, https://doi.org/10.1002/tie.5060080409

Vernon, R. (1996). Passing through regionalism:the transition to global markets, Journal of World Trade, 19(6), pp.621-633, https://doi.org/10.1111/j.1467-9701.1996.tb00703.x

WEF (2017). The Global Competitiveness Report 2016-2017, Geneva: World Economic Forum.

Yeaple, S. R., Golub, S. S. (2007). International Productivity Differences, Infrastructure, and Comparative Advantage, Review of Int'l Economics, 15(2), pp.223-242, https://doi.org/10.1111/j.14679396.2007.00667.x

Tavares, A. T., Young, S. (2005). FDI and Multinationals:Patterns, Impacts and Policies, Int'l Journal of the Economics of Business, 12(1), pp.3-16, https://doi.org/1080/1357151042000323148 
Young, S., Tavares, A. T. (2008). Achieving A Balance In The Rights/Obligations of Companies/Countries, FDI, Location and Competitiveness Progress in Int'l Business Research, Oxford, Elsevier Ltd, Ed. John H. Dunning, Philippe Gugler, UK, 2, pp.255-277.

1 This study is derived from the PhD thesis accepted by Istanbul University Institute of Social Sciences under the title of "The Impacts of Logistics Performance upon Economic Growth: A Proposal of Conceptual Model From The Perspective of EU-Turkey Customs Union Dynamic Effects”.

2 To understand the structure of complex models via equations is difficult, Path Analysis in contrast provide holistic view on relations among variables (Bayram, 2013). Better visuality through Path Analysis make direct as well as indirect effects more apparent (Sobel, 1982). Measuring equations simultaneously makes comprehension easier (Lei ve Wu, 2007). 